\section{Effect of Using Biomimetic Analogs on Dentin Remineralization with Bioactive Cements}

\author{
Noha Y Sadoon ${ }^{1} @$, Salma M Fathy²@- Manal F Osman ${ }^{3}[0$
}

'Dental Section, Students Hospital, Zagazig University, Egypt ${ }^{2}$ Dental Biomaterials Dept., Faculty of Dental and Oral Medicine, Zagazig University, Egypt ${ }^{3}$ Dental Biomaterials Dept, Faculty of Dentistry, Mansoura University, Egypt

Correspondence: Salma M Fathy, Lecturer of Dental Biomaterials Dept., Faculty of Oral and Dental Medicine, Zagazig University, Zagazig, Sharkia, Egypt. Tel: +201000153552 . e-mail: Salmafathy_dent@mans.edu.eg

Key Words: biomineralization, biomimetic analogs; caries affected dentin, calcium silicate cement, calcium hydroxide cements.

\section{Introduction}

The know how to manage and deal with the demineralized dentin is greatly important. Most of the recent conservative approaches avoid unnecessary tooth structure removal and leave caries affected dentin as the clinical bonding substrate (1). The usage of remineralizing material, on the other side, is crucially important. Variety of dental materials, with different bioactive abilities, is used nowadays. Some of them are calcium silicate, calcium hydroxide or hydroxyapatite based $(2,3)$ Most of these materials, like Biodentine, Theracal and MTA, have shown good signs of remineralization to tooth structure and in contact with living cells (4-7). However, the remineralization process, in accordance with such materials, will take place when they come in contact with simulated body fluids containing phosphate (8). Residual mineral crystallites only will act as seed sites for remineralization and epitaxial growth of crystals apatite (9). Other areas of the demineralized dentin depleted from these seeds will remain un-mineralized.

In order to have reliable bottom-up dentin remineralization, evidence of minerals formation should be detected within intra-fibrilar and extra-fibrilar demineralized collagen fibrils (10). Accordingly, the presence of biomimetic analogs, to non-collagenous proteins (NCPs) in dentin matrix, may have an important role in such situations even with the advancement of variable ion-releasing materials. These proteins play critical roles in controlling apatite nucleation and growth in collagenous tissues (11). It was proved that addition of NCPs analogs to mineral trioxide (MTA) formula significantly improved remineralization of demineralized dentin whether dentin adhesive was applied or not (7). Despite of these previous findings, no attempt to apply biomimetic analogs with recent formulations of cement materials was reported.

The current study aimed to asses the remineralizing ability of these pulp protecting materials in presence and in absence of NCPs analogs. The null hypothesis is that the calcium silicate and calcium hydroxide based materials' remineralizing ability will not be affected with the presence of NCPs analogs.

\section{Material and Methods}

Two famous and recent cements were used, one based on calcium silicate (BiodentineTM, Septodont Corporation, 
$\mathrm{PA}$, France) and the other based on hydroxyapatite in a urethane dimethacrylate resin (Lime-liteTM, Pulpdent Corporation, Watertown, MA, USA). NCPs biomimetic analogs (BAs) used were poly acrylic acid (PAA) and sodium tri-meta-phosphate (STMP) $\left(\mathrm{Na}_{3} \mathrm{P}_{3} \mathrm{O}_{9}\right)$. They were purchased from Sigma-Aldrich, St- Louis, MO, USA. Sixty-eight, for each test of both EDX \& surface micro-hardness, freshly extracted human third molars (due to periodontal or impaction reasons) were collected from Mansoura University external clinic section under ethical committee number M22120219. All teeth were intact, non- carious and unrestored. Each tooth was thoroughly washed under distilled water. A sharp hand sickle scalar (Prima-Dent international, Frank. F Germany) was used to remove any soft tissue remnants. The teeth were stored in $0.1 \mathrm{wt} . \%$ thymol in distilled water at $4{ }^{\circ} \mathrm{C}$ until the time of cavity preparation and testing.

The occlusal enamel of the crowns was totally removed using a diamond wheel bur ( $\mathrm{Wr}-13$ high speed wheel shape diamond dental bur, Shenzhen Dian Fong Abrasives Co, Guangdong, China) fixed in water-cooled high-speed contra hand-piece (Sirona T3 Racer, Dentsply, Germany). The dentin surfaces were thoroughly checked by eye inspection and diagnostic probe for absence of enamel and/or pulp tissue. After that, two standard occluso-proximal circular cavities ( $2 \mathrm{~mm}$ diameter $\times 0.5 \mathrm{~mm}$ depth) were prepared within each dentin surface using a low speed wheel shape diamond dental bur (Shenzhen Dian Fong Abrasives Co, Guangdong, China) of diameter $2 \mathrm{~mm}$ and height 0.5 $\mathrm{mm}$ fixed in water cooled low speed contra hand-piece (External spray NSK Ex-203 low speed dental hand-piece, China). All dentin surfaces were coated with two layers of acid-resistant varnish (nail polish, Revelon, Paris, France) except the internal cavities' surfaces and a small rim of dentin (1 to $2 \mathrm{~mm}$ ) surrounding each cavity (Fig. 1). The apices of the roots were closed with composite resin (Capo universal, Mani Schutz Dental, Rosbach, Germany).

\section{Artificial Caries Induction and Biomimetic Analogs (BAs) Preparation.}

It was induced by $\mathrm{pH}$ cycling within the unprotected dentin surfaces. De- and re-mineralizing solutions with the same composition and protocol previously utilized was prepared and used (12). The teeth were cycled in 150 $\mathrm{mL}$, for each subgroup, of both solutions for $8 \mathrm{~h}$ in the demineralizing solution and $16 \mathrm{~h}$ in the remineralizing solution. Both solutions were refreshed in each new cycle. This procedure was carried out for 14 days at room temperature without agitation (12). After $\mathrm{pH}$ cycling, each tooth was rinsed with distilled water and air-dried then kept in distillated water for one day before testing. A solution of 2.5 wt $\%$ STMP was prepared (13). Since protein phosphorylation with STMP requires alkaline hydrolysis into linear form, it was first prepared at $\mathrm{pH} 12$ for $5 \mathrm{~h}$ then neutralized to $\mathrm{pH} 7.4$ using $\mathrm{HCl}$ and $\mathrm{NaOH}$ buffers (14). $500 \mu \mathrm{g} / \mathrm{mL}(0.025 \mathrm{~g})$ of PAA powder was dissolved in $50 \mathrm{ml}$ deionized water then the solution was buffered to $\mathrm{pH} 7.4$ using $\mathrm{NaOH}$ and $\mathrm{HCl}$ buffers to be prepared for each subgroup.

After $\mathrm{pH}$ cycling, one cavity in each tooth, with its demineralized surrounding rim, was then coated with two layers of the previously prepared STMP solution using micro applicator and left to dry for five minutes. After drying, the same cavity was coated with two layers of previously prepared PAA solution using another micro applicator then left for another five minutes to dry while the other cavity in each tooth was left uncoated. Sixty teeth with coated and uncoated cavities were used for each of the tested materials (calcium silicate-based and hydroxyapetite-based cements) and eight for negative control. Each tooth had two (coated and uncoated) cavities, which were filled with the same tested material according to manufacturer's instructions. A group of untreated teeth were left without any cement materials to be used as control. Afterwards, all teeth were sectioned vertically in bucco-lingual direction into two halves using micro-saw (Isomet 4000 micro-saw; Buehler, Lake Bluff, IL, USA) at $2500 \mathrm{rpm}$ speed under copious water spray coolant. Each half contained area of sound protected dentin and one restored cavity surrounded by a rim of demineralized dentin. The teeth halves with restored cavities without BAs were stored in $150 \mathrm{ml}$ of simulated body fluid (SBF) of $\mathrm{pH}$ 7.4. SBF that was prepared similarly to a previously described literature (15). The other teeth halves with restored and coated cavities with BAs were stored in SBF with $500 \mu \mathrm{g} / \mathrm{mL}(0.5 \mathrm{~g} / \mathrm{L})$ PAA at ambient temperature. Both SBFs were refreshed weekly. The specimens were collected at intervals of 1, 6 and 12 weeks to monitor remineralization process.

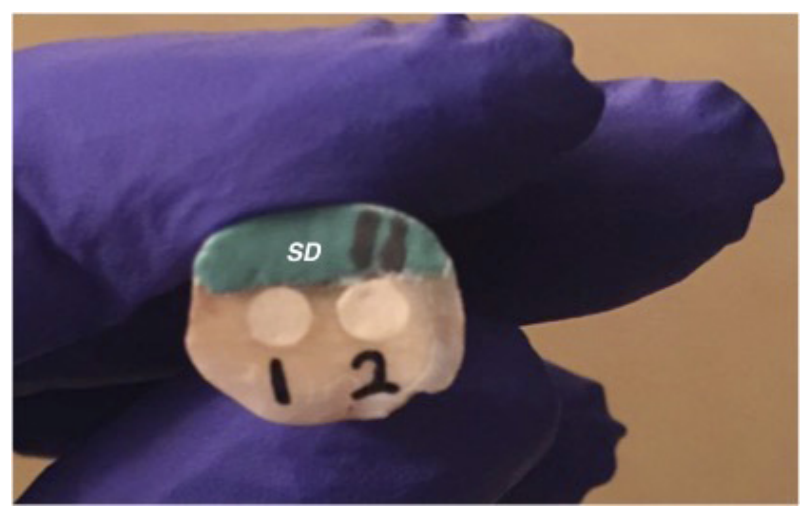

Figure 1. One tooth as a specimen with prepared and filled round cavities, one cavity received pretreatment with biomimetic analogs and the other did not receive. It also shows area of protected sound dentin (SD) with blue varnish to be taken as reference within each specimen. 


\section{X-ray Spectroscopy (EDX) and Optical Microscopy}

First two specimens were collected after each of the target three intervals. They were dehydrated in ethyl alcohol of 70\% concentration (Pharmaoverseas, Egypt) for 30 min then in 95\% concentration (M.W. 46.07, Union Chemicals, Egypt) for $1 \mathrm{~h}$ (16). Then the mineral content on demineralized rim around each cavity was evaluated using energy dispersive spectroscopy (EDX) apparatus (JEOL, Oxford X-Max 20, UK) attached to JSM-6510LV Scanning Electron Microscope (SEM) (JEOL, Tokyo, Japan). As it was reported that these hydraulic cements form crystal deposits at the interface with dentin when stored at physiologic solutions containing phosphate (17). When the mineral content was found to be different from the negative control specimens, the rest of ten specimens from each material subgroup were then collected, sectioned bucco-lingually perpendicular to the cement-dentin interface using water-cooling system and Isomet diamond saw. They were then chemically dehydrated as the abovementioned protocol and the interface directly beneath the tested cements was examined by EDX for surface mineral content. Afterwards, three randomly selected specimens from negative (demineralized untreated and unrestored) and positive (sound and protected) control dentin specimen and restored groups were further sectioned bucco-lingually into very thin ground sections of 0.33 to $0.4 \mathrm{~mm}$ in thickness using the Isomet microsaw.

An optical microscope (Olympus Corporation, Tokyo, Japan) connected to digital camera (TUCSEN 2.0 MP USB microscope digital camera, China) was used to examine areas of sound, demineralized and remineralized dentin of those teeth ground sections (18).

\section{Surface Microhadrness Testing}

The same protocol for EDX was followed with surface microhardness except for the chemical dehydration of the specimens. They were rinsed with distilled water and dried with tissue so that they are still retaining humidity. Then they were fixed in acrylic blocks, after being sectioned bucco-lingually, prior to the examination of dentin interface directly beneath the tested cements with or without BAs. A microhardness tester (Tukon 1102, Wilson, Buehler) was used with a Vickers diamond indenter at a load of $25 \mathrm{~g}$ and a dwell time of 10 seconds. Three indentations were done in the surface of sound and artificially demineralized dentin surfaces (19).

\section{Statistical Analysis}

It was achieved using SPSS 16.0 (SPSS, Chicago, IL, USA) for Windows. Two-way ANOVA was conducted to evaluate the effect of both variables (materials group and time intervals) on $\mathrm{Ca}$ and $\mathrm{P}$ ions content and surface hardness in artificially demineralized dentin. Least significance Difference (LSD) test was done afterwards to evaluate the significance difference between groups in each test.

\section{Results}

Remineralizing Ability Results

Energy-Dispersive X-Ray Spectroscopy Elemental Analysis (EDX)

EDX analysis of artificially induced demineralized dentin (DMD) at cement/dentin interface showed increase in $\mathrm{Ca}$ and $\mathrm{P}$ surface contents. They showed variable increase in minerals in comparison with SD of the same specimen with storage period prolongation (Fig. 2). There was a statistically significant difference in Ca levels among all tested materials groups $(p<0.05)$ within the three different storage periods ( 1,6 and 12 weeks). Calcium silicate-based cement + BAs group showed the highest mean values of Ca levels, except for sound dentin groups, after 12 weeks of storage $(23.3 \pm 2.9)$. On the other hand, hydroxyapatitebased cement groups showed the least mean values of Ca levels $(14.0 \pm 2.5)$ after total period of storage. Both calcium silicate-based and hydroxyapatite-based cement groups with added BAs showed statistically significant increase in Ca \& P values $(p<0.05)$ than their base groups. Two-way ANOVA analysis showed that different tested materials had a statistically significant effect $(p<0.05)$ on $\mathrm{Ca}, \mathrm{P}$ and surface hardness mean values. It also showed that the effect of storage time through three periods had a statistically significant effect $(p<0.05)$ on the increase within $P$ levels and surface hardness while it had no statistically significant effect $(p>0.05)$ on Ca mean values (Table 1). Figure $3 A, B$ shows a bar chart of mean values and standard deviations of all tested groups.

\section{Optical Microscope Analysis of DMD Surfaces}

Unstained ground sections (GSs) of teeth showed a lighter appearance of sound dentin with the appearance of S-shaped curvature of dentinal tubules and interglobular dentin. On the other hand, it showed darker appearance with dead tracts (DTs) in DMD after $\mathrm{pH}$ cycling. The latter DTs are empty dentinal tubules whose contents coagulate and die due to the action of artificial caries induction process. The DMD, in close contact to tested materials, un-stained GSs of all tested groups at different storage periods are shown in Figure 4. The 12th week calcium silicate-based cement + BAs G.S showed the largest area of remineralization or light zone (LZ). While the 1st week hydroxyapatite-based cement G.S showed the least areas of LZ.

\section{Surface Mechanical Evaluation (Microhardness)}

Calcium silicate-based cement + BAs groups showed 
the highest mean values of surface hardness, except for sound dentin groups, especially after 6th and 12th week of storage $\left(38.200 \pm 2.911,55.380 \pm 0.785 \mathrm{~kg} \cdot \mathrm{mm}^{-2}\right.$, respectively). On the other hand, hydroxyapatite-based cement groups showed the least mean values of surface hardness especially after 1st and 6th week of storage $\left(33.725 \pm 1.810,33.900 \pm 2.162 \mathrm{~kg} \cdot \mathrm{mm}^{-2}\right.$, respectively). There was a statistically significant difference among all tested materials groups $(\mathrm{p}<0.05)$ within the three different storage periods (1, 6 and 12 weeks) (Fig. 3C) and Table 2.

\section{Discussion}

Despite of their advantages, calcium silicate and calcium hydroxide based cements ability to restore the mechanical properties of remineralized dentin may be still questionable. The present study was conducted to investigate the remineralization potential of two pulp protecting materials with/without the use of NCPs BAs and hence the impact on restoring dentin mechanical properties. The first cement is calcium silicate based and resin free cement (Biodentine ${ }^{\mathrm{TM}}$ Septodont, France) and the second is resin based calcium hydroxide cement (Lime-lite ${ }^{\mathrm{TM}}$, Pulpdent, USA).

Polyanionic molecules in combination with cement materials were used to mimic the functions of matrix proteins. They are in the form of PAA $\left(\mathrm{C}_{3} \mathrm{H}_{4} \mathrm{O}_{2}\right) n$ and STMP $\left(\mathrm{Na}_{3} \mathrm{P}_{3} \mathrm{O}_{9}\right)(9)$. The former analog was used as a sequestration agent. It has the ability to stabilize remineralizing ions derived from the set pulp protecting materials and SBF in the form of liquid-like nanoparticles. As a result, they could penetrate the water compartments of collagen fibrils (20). The latter analog mimics the collagen-binding function of matrix phosphoproteins. It includes phosphate
After 6 Weeks
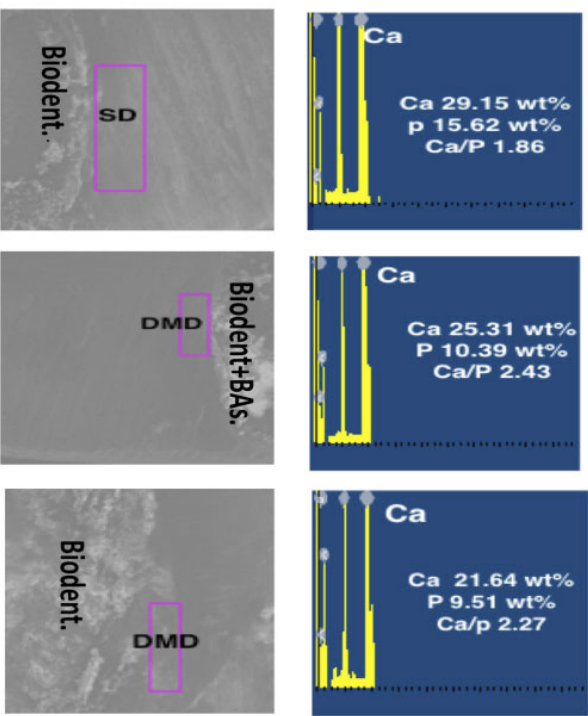

After 6 Weeks
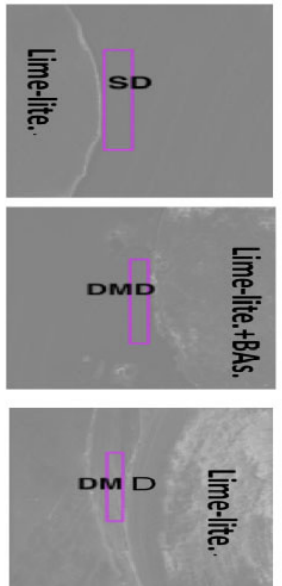
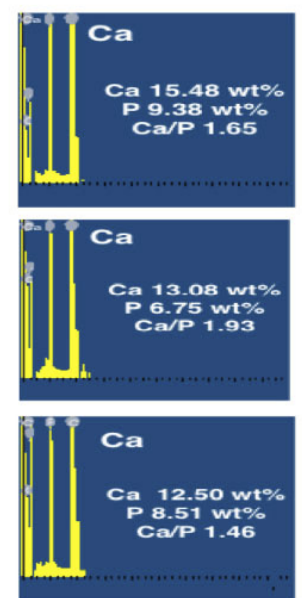

After 12 weeks
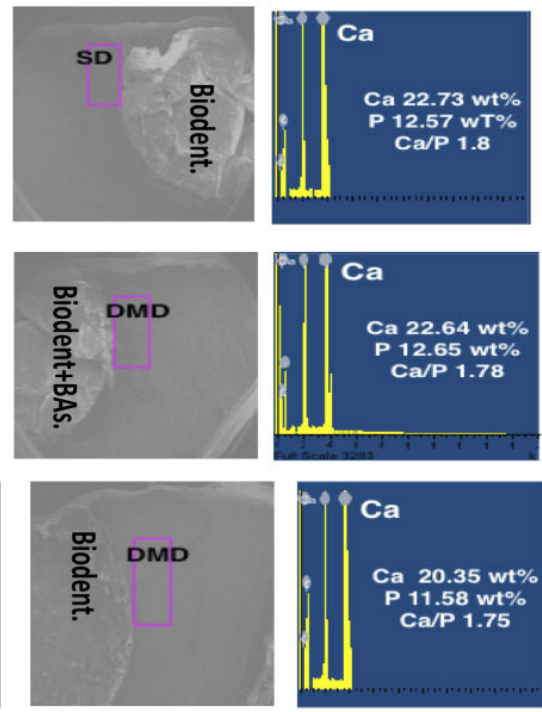

After 12 weeks
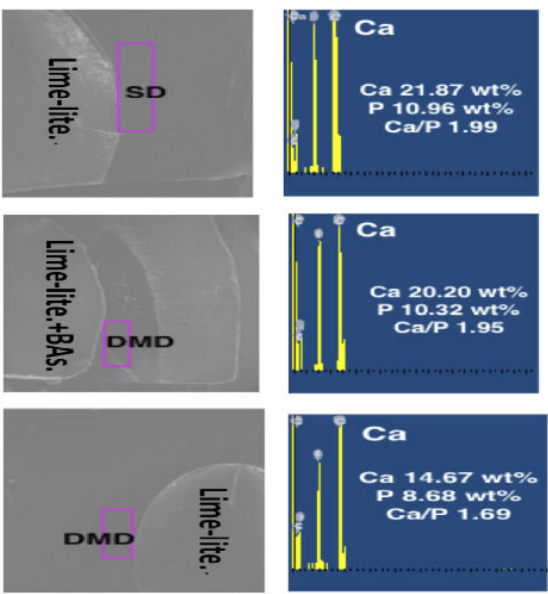

Figure 2. EDX analysis of sound dentin (SD) and demineralized dentine (DMD) for Biodentine and Limelite in presence or absence of biomimetic analogs (BAs) showing increase in Ca \& $\mathrm{P}$ wt\% in relation their \% in SD of the same specimen. Records are taken form the same specimen for each case after 6 and 12 weeks of storage in SBF. 
groups that are rendered immobile on the collagen fibrils to draw calcium ions and direct appetite crystals nucleation within the gap zones of collagen fibrils (intrafibrilar appetites) (10). The previous analogs were applied to artificially induced carious lesions, within the prepared
Table 1. Effect of different tested materials and storage periods on Ca, P and surface hardness (kg. $\left.\mathrm{mm}^{-2}\right)$ mean values of tested groups.

\begin{tabular}{|c|c|c|c|c|c|c|}
\hline Variable & Groups & $\begin{array}{c}\mathrm{Ca} \\
(\text { mean } \pm \mathrm{SD})\end{array}$ & $\mathrm{p}$ value & $\begin{array}{c}\mathrm{P} \\
(\text { mean } \pm \mathrm{SD})\end{array}$ & $\begin{array}{c}\text { Hardness } \\
(\text { mean } \pm \text { SD) }\end{array}$ & $\mathrm{p}$ value \\
\hline \multirow{5}{*}{$\begin{array}{l}\text { Dentin + } \\
\text { Material }\end{array}$} & Sound dentin & $23.9 \pm 3.2^{\mathrm{a}}$ & \multirow{5}{*}{$0.0001^{*}$} & $12.9 \pm 2.1^{\mathrm{a}}$ & $45.1 \pm 6.6^{\mathrm{a}}$ & \multirow{5}{*}{$0.0001^{*}$} \\
\hline & Biodentine + BAs & $23.3 \pm 2.9^{\mathrm{a}}$ & & $12.4 \pm 1.9^{a}$ & $42.8 \pm 8.9^{b}$ & \\
\hline & Biodentine & $20.5 \pm 2.2^{b}$ & & $10.4 \pm 1.4^{b}$ & $42.8 \pm 8.6^{b}$ & \\
\hline & Lime-lite + BAs & $16.8 \pm 3.4^{\mathrm{c}}$ & & $9.9 \pm 1.9^{b}$ & $39.5 \pm 7.5^{\mathrm{c}}$ & \\
\hline & Lime-lite & $14.0 \pm 2.5^{\mathrm{d}}$ & & $9.2 \pm 1.3^{b}$ & $37.7 \pm 5.3^{c}$ & \\
\hline \multirow{3}{*}{$\begin{array}{l}\text { Storage } \\
\text { period }\end{array}$} & $1^{\text {st }}$ week & $20.2 \pm 5.0^{\mathrm{a}}$ & \multirow{3}{*}{0.114} & $11.66 \pm 2.3^{a}$ & $37.82 \pm 5.0^{b}$ & \multirow{3}{*}{$0.008^{*}$} \\
\hline & $6^{\text {th }}$ week & $18.9 \pm 5.8^{a}$ & & $10.16 \pm 2.3^{b}$ & $38.83 \pm 4.5^{b}$ & \\
\hline & $12^{\text {th }}$ week & $21.0 \pm 3.4^{\mathrm{a}}$ & & $11.94 \pm 2.0^{\mathrm{a}}$ & $51.77 \pm 5.1^{\mathrm{a}}$ & \\
\hline
\end{tabular}

*statistically significant difference. a-d means: same letters in each variable row are not significantly different at $p<0.05$. cavities, throughout $\mathrm{pH}-$ cycling model. This model mimics the natural dynamic process of caries formation that involves alternating de- and re-mineralization (12). In addition, it is highly appropriate method to produce artificially affected caries dentin layer with similar hardness values in comparison to naturally produced dentin lesion until the depth of $40 \mu \mathrm{m}$ (12). However, the period of de- and re-mineralization is
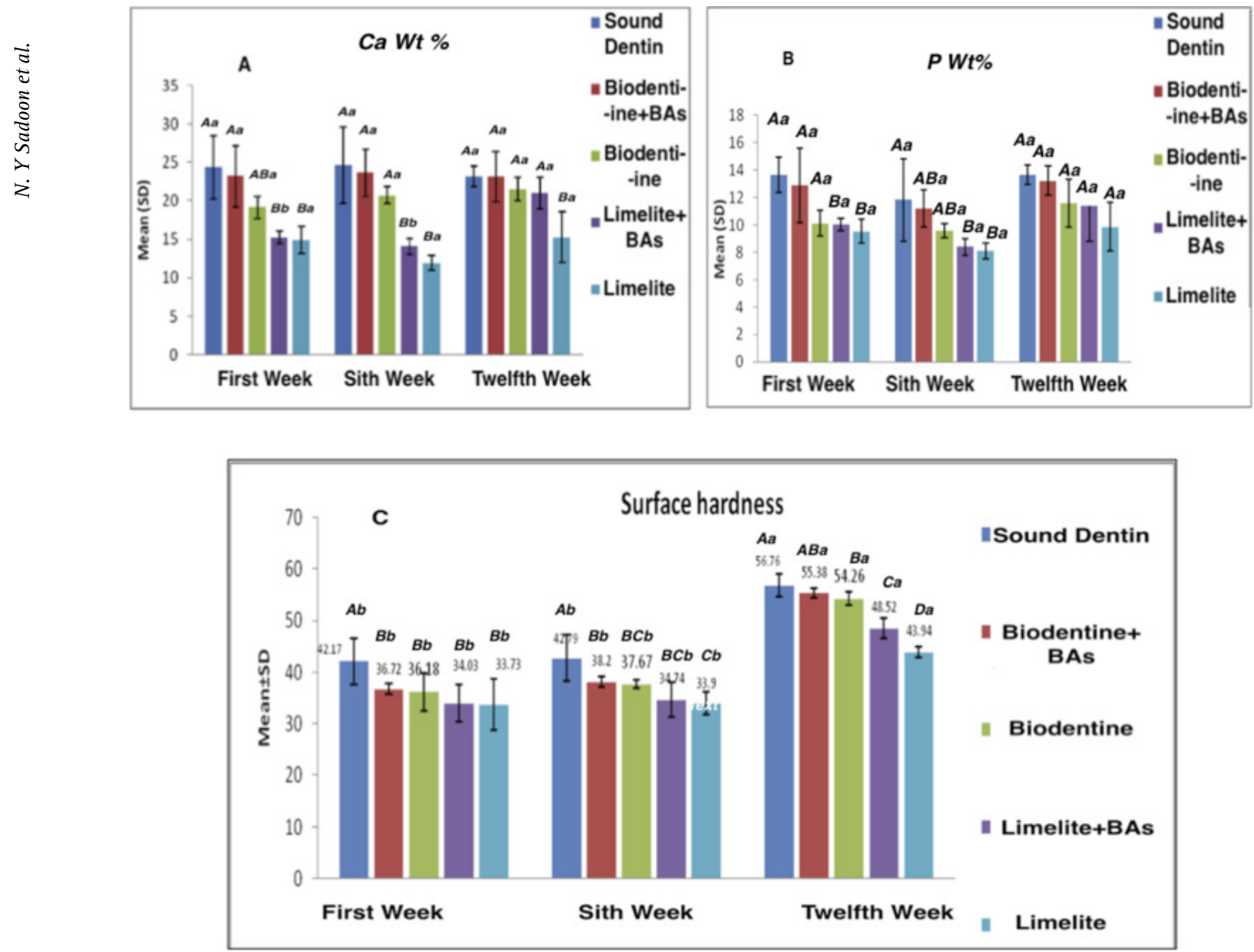

Figure 3. Bar charts showing the mean values of $\mathrm{Ca} \mathrm{Wt} \% \pm$ standard deviations (A) and mean values of $\mathrm{P}$ Wt $\% \pm$ standard deviations. They are highest for Biodentine groups approaching SD and lowest for Limelite groups. The third bar chart (C) shows the highest hardness mean values $\left(\mathrm{kg} . \mathrm{mm}^{-2}\right)$ for Biodentine+BAs and Biodentine with sound dentin after 12 weeks of storage in SBF. 
not well defined. Furthermore, this method did not employ saliva and biofilm. In addition, it does not consider the

Table 2. Mean values and SD of surface hardness (kg.mm-2) of all tested groups at different storage periods

\begin{tabular}{lcccccc}
\hline Period & $\begin{array}{c}\text { Sound } \\
\text { dentin }\end{array}$ & $\begin{array}{c}\text { Biodentine }+ \\
\text { biomimetic } \\
\text { analogs }\end{array}$ & Biodentine & $\begin{array}{c}\text { Limelite } \\
\text { +biomimetic } \\
\text { analogs }\end{array}$ & Limelite & p value \\
\hline $1^{\text {st }}$ week & $42.17 \pm 4.5^{\mathrm{Ab}}$ & $36.72 \pm 4.4^{\mathrm{Bb}}$ & $36.18 \pm 2.3^{\mathrm{Bb}}$ & $34.03 \pm 3.6^{\mathrm{Bb}}$ & $33.73 \pm 1.8^{\mathrm{Bb}}$ & $0.0027^{*}$ \\
$6^{\text {th }}$ week & $42.79 \pm 3.7^{\mathrm{Ab}}$ & $38.20 \pm 2.9^{\mathrm{Bb}}$ & $37.67 \pm 2.0^{\mathrm{BCb}}$ & $34.74 \pm 3.3^{\mathrm{BCb}}$ & $33.90 \pm 2.2^{\mathrm{Cb}}$ & $0.0001^{*}$ \\
$12^{\text {th }}$ week & $56.76 \pm 1.7^{\mathrm{Aa}}$ & $55.38 \pm 0.8^{\mathrm{ABa}}$ & $54.26 \pm 0.6^{\mathrm{Ba}}$ & $48.52 \pm 2.0^{\mathrm{Ca}}$ & $43.94 \pm 1.0^{\mathrm{Da}}$ & $0.0001^{*}$ \\
p value & $0.0001^{*}$ & $0.0001^{*}$ & $0.0001^{*}$ & $0.0001^{*}$ & 0.4390 & \\
\hline
\end{tabular}

*statistically significant difference. A-C: same capital letters in each row are not statistically significant different at $\mathrm{p}<0.05$. $\mathrm{a}-\mathrm{b}$ : same small letters in each column are not statistically significant different at $\mathrm{p}<0.05$. complexity of the oral environment and induces shallower artificial caries lesions than naturally generated ones (12).

Generally, EDX analysis displayed that calcium silicatebased cement groups showed higher content of $\mathrm{Ca}$ and $\mathrm{P}$ surface ions on DMD than hydroxyapatite-based cement groups. These results are in accordance with a previousstudy (2) that correlated the high Ca release of calcium silicate-based cement composition. It has three forms of Ca components.
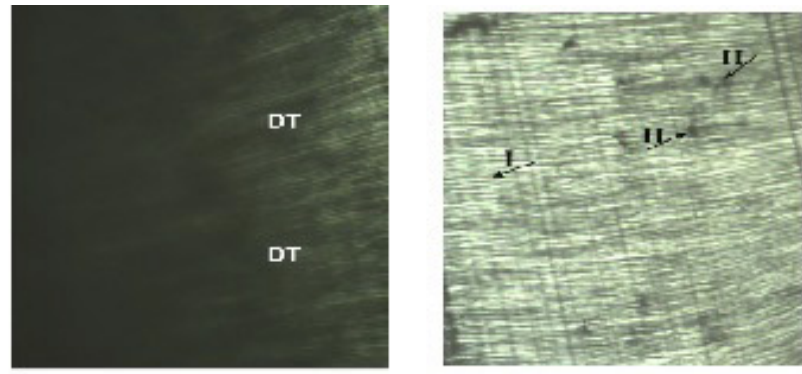

Lime-Lite Lime-Lite+BAs Biodent. Biodent.+BAs
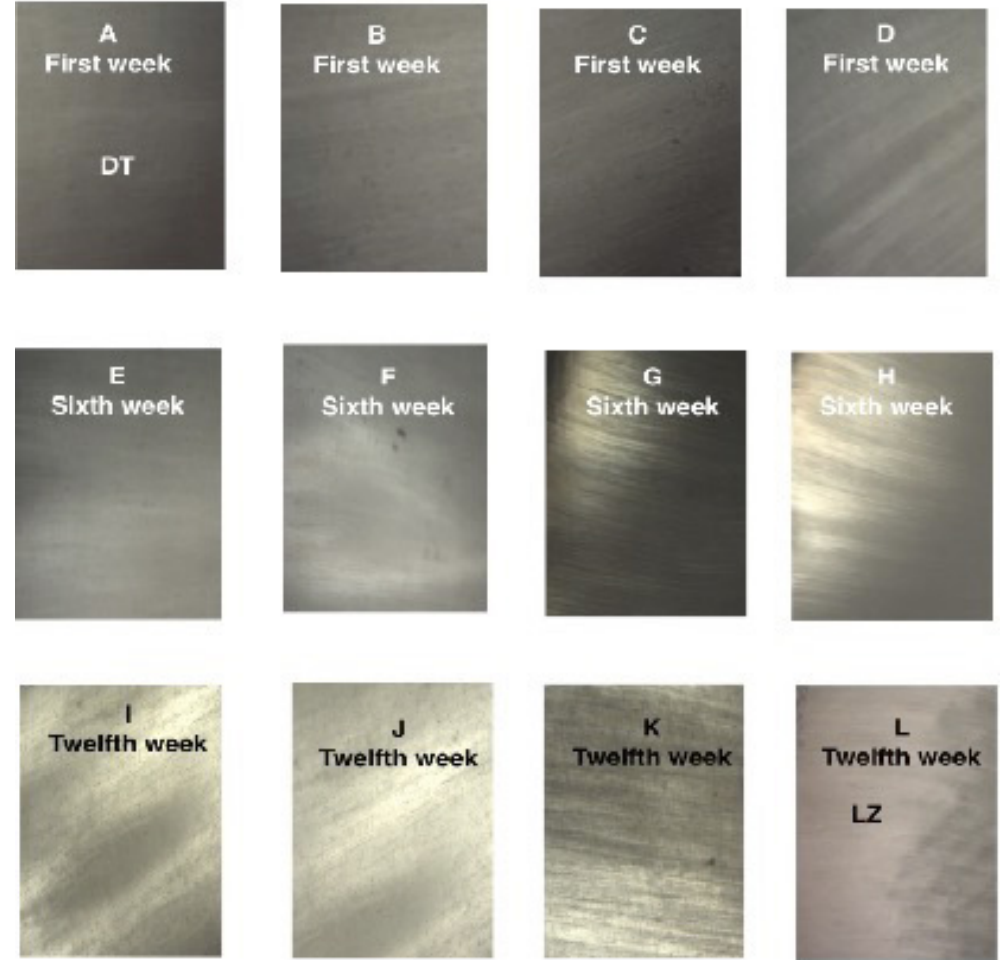

Figure 4. Un-stained ground sections (GS) under light microscope showing sound dentin with S-shaped dentinal tubules (I) and inter-globular dentin (II) (top right image) \& artificially demineralized dentin (DMD) with dead tracts (DT) after pH cycling (top left image) (Magnification: 16x). GSs for DMD of tested groups after three intervals are shown below in 4 columns. (A) 1st week Limelite G.S shows the largest area of dead tracts (DT) than (D) least appearance of DT after 1 week for Biodentine+BAs. The lightness of the images increases with prolongation of storage period. The twelfth week group is the highest in lightness with the largest light zone (LZ) for Biodentine + BAs G.S (L) (Magnification: 16x). 
Firstly, calcium silicate component, secondly, calcium carbonate component, both in its powder, and finally calcium chloride in its liquid which all can act as $\mathrm{Ca}$ ions sources. In addition, its liquid has a hydrosoluble polymer that serves as a water reducing agent and allows for calcium silicate-based cement prolonged hydration (21). The hydration process in the former cement occurs in an efficient aqueous medium from the liquid and the moisture found in dentin. The reaction results in the formation of calcium silicate hydrate and calcium hydroxide that is produced in large amount (22-24). On the other hand, hydroxyapatite-based cement in presence and absence of BAs showed less $\mathrm{Ca}$ ions content on DMD surface through the three periods of storage than calcium silicate-based cement groups. It may be attributed to the presence of urethane dimethacrylate resin in its composition (25). This resin-based heterogeneous structure may impede enough moisture diffusion within the material which is necessary for complete material hydration and dissociation for ions release $(26,27)$.

In the normal bio-mineralization process in dentin NCPs, like dentin matrix protein 1 (DMP1), are produced by odontoblasts; distributed between the collagen fibrils$$
\text { the }
$$

$$
\text { pitsing }
$$
phosphatase enzyme to initiate mineralization (29,30).The present study used an analog to NCPs, which was PAA in presence of STMP and a bioactive cement in an attempt to simulate the process of normal situation. However, within the normal in-vivo situation, the process is more complicated. It depends on the ability of such NCPs to interact with amorphous calcium phosphate to form a nano-composite within the gap between collage fibrils, intra-fibrilar not extra-fibrilar, that finally transform into HAp crystals (14). The biomimetic remineralization strategy is based on the replacement of free and loosely bounded water between collagen fibrils with apatite crystallites (31). That was reported to be a non-classical bottom-up remineralization approach that if successfully occurred will restore the mechanical properties of DMD up to $74 \%$ of its after 7-10 days and up to $91 \%$ its elastic after 28 days of storage (32).

The presence of BAs has significantly improved the remineralizing ion surface content in DMD especially within first week for calcium silicate-based cement within the current study. The analogs provided sustained high ion content for the total period of storage. After the total period of storage, the remineralizing ion content was significantly higher for hydroxyapatite-based cement with analogs than Limlite without analogs application. These findings are in agreement with a recent (33) study, which explained this time-dependent beneficial effect of using BAs which could be associated with their relatively slow release kinetics. Previous findings showed continuous release of STMP from set MTA blocks during 6 weeks. This improvement of ion release with the presence of analogs may have been promoted in two ways: firstly, the dual BAs ability to stabilize $C$ a and $P$ as well as ordered deposition of intra-fibrilar apatite platelets. Secondly, STMP can serve as a supplementary phosphate source that may promote $P$ release as well (7). In addition, the presence of BAs in a direct contact with the cement materials, like their application within the cavity below the cement material as the present study did, may fastened the ion release kinetics from the materials (7).

The presence of BAs did not only improve the ion concentration but also the surface microhardness of DMD in close contact to cement materials after total period of storage. At different periods of storage, calcium silicatebased cement with analogs group showed the highest surface microhardness mean values. The presence of analogs was reported to restore the surface mechanical properties of DMD matrix (32). This may be attributed to the ability of biomimetic remineralization (intra-fibrilar minerals deposition) to protect the denuded collagen fibrils from degradation and restore their dynamic mechanical properties (34).

Based on the findings of the present study, calcium silicate-based cement had a significantly better remineralization potential than hydroxyapatite-based cement either in presence or absence of biomimetic analogs. The application of BAs together with both cement materials has significantly enriched the surface with ions essential for remineralization process. Furthermore, it significantly improved the surface microhardness of DMD that approached healthy dentin values after 12 weeks of storage.

\section{Resumo}

Este estudo avaliou o impacto do uso de análogos biomiméticos (ácido poli-acrilico e tri-meta-fosfato de sódio) na remineralização da dentina usando dois materiais de cimento, o primeiro à base de silicato de cálcio e o segundo à base de hidróxido de cálcio. Duas cavidades oclusais padronizadas (mesial e distal) foram preparadas na dentina após a remoção do esmalte oclusal. A dentina desmineralizada artificial foi induzida por ciclagem de $\mathrm{pH}$ (8 $\mathrm{h}$ em soluções desmineralizantes e $16 \mathrm{~h}$ em soluções remineralizantes). Cavidades desmineralizadas foram divididas em quatro grupos; dois grupos receberam materiais de cimento. Os outros grupos foram tratados primeiro com análogos biomiméticos e depois restaurados com materiais de cimento de celulose. Os dentes foram seccionados bucolingualmente em duas metades. As cavidades tratadas com análogos foram armazenadas em fluido corporal simulado contendo ácido poli-acrílico. As cavidades não tratadas foram armazenadas apenas em fluido corporal simulado. Secções não coradas de dentina desmineralizada foram examinadas usando microscópio óptico. As amostras foram examinadas após 1,6 e 12 semanas de armazenamento usando Espectroscopia de Raios-X dispersiva por energia (EDX) e microdureza Vickers. ANOVA a dois fatores foi usada para analisar os dados estatisticamente. 0 
grupo de cimento à base de silicato de cálcio com análogos biomiméticos apresentou os maiores percentagens em peso estatisticamente significantes de cálcio e fósforo, além dos maiores valores de dureza superficial após 12 semanas de armazenamento. Seções desmineralizadas de dentina mostraram aumento nas zonas de luz após o periodo total de armazenamento. 0 cimento à base de silicato de cálcio mostrou a melhor capacidade de enriquecer a dentina cariada artificial com íons para remineralização. 0 uso de análogos biomiméticos teve um impacto significativo na melhoria da dureza superficial da dentina desmineralizada.

\section{References}

1. Sauro $S$, Osorio $R$, Watson TF, Toledano M. Influence of phosphoproteins' biomimetic analogs on remineralization of mineral-depleted resindentin interfaces created with ion-releasing resin-based systems. Dent Mater. 2015;31:759-777.

2. Gandolfi MG, Siboni $F$, Botero $T$, Bossù $M$, Riccitiello F, Prati C. Calcium silicate and calcium hydroxide materials for pulp capping: biointeractivity, porosity, solubility and bioactivity of current formulations. J Appl Biomater Funct Mater 2015;13:43-60.

3. Niu LN, Jiao K, Wang T Da, Zhang W, Camilleri J, Bergeron BE, et al. A review of the bioactivity of hydraulic calcium silicate cements. J Dent 2014;42:517-533.

4. Gandolfi MG, Siboni F, Prati C. Chemical-physical properties of TheraCal, a novel light-curable MTA-like material for pulp capping. Int Endod J 2012;45:571-579.

5. Kim JR, Nosrat A, Fouad AF. Interfacial characteristics of Biodentine and MTA with dentine in simulated body fluid. J Dent 2015;43:24124-7.

6. Lin JC, Lu JX, Zeng Q, Zhao W, Li WQ, Ling JQ. Comparison of mineral trioxide aggregate and calcium hydroxide for apexification of immature permanent teeth: A systematic review and meta-analysis. J Formos Med Assoc 2016;115:523-530.

7. Qi YP, Li N, Niu LN, Primus CM, Ling JQ, Pashley DH, et al. Remineralization of artificial dentinal caries lesions by biomimetically modified mineral trioxide aggregate. Acta Biomater 2012;8:836-842.

8. Darvell BW, Wu RCT. MTA - An hydraulic silicate cement: review update and setting reaction. Dent Mater 2011;27:407-22.

9. Koutsoukos PG, Nancollas GH. Crystal Growth of Calcium Phosphates. J Cryst Growth 1981;53:10-19.

10. Liu Y, Mai S, Li N, Yiu CKY, Mao J, Pashley DH, et al. Differences between top-down and bottom-up approaches in mineralizing thick, partially demineralized collagen scaffolds. Acta Biomater 2011;7:1742-1751.

11. Forsback $A P$, Areva $S$, Salonen JI. Mineralization of dentin induced by treatment with bioactive glass S53P4 in vitro. Acta Odontol Scand 2004;62:14-20.

12. Marquezan M, Corrêa FNP, Sanabe ME, Rodrigues Filho LE, Hebling J, Guedes-Pinto AC, et al. Artificial methods of dentine caries induction: A hardness and morphological comparative study. Arch Oral Biol 2009;54:1111-117.

13. Liang K, Weir MD, Xie X, Wang L, Reynolds MA, Li J, et al. Dentin remineralization in acid challenge environment via PAMAM and calcium phosphate composite. Dent Mater 2016;32:1429-1440.

14. He G, Gajjeraman S, Schultz D, Cookson D, Oin C, Butler WT, et al. Spatially and temporally controlled biomineralization is facilitated by interaction between self-assembled dentin matrix protein 1 and calcium phosphate nuclei in solution. Biochemistry 2005;44(49):1614016148.

15. Liu Y, Li N, Qi Y, Niu LN, Elshafiy S, Mao J, et al. The use of sodium trimetaphosphate as a biomimetic analog of matrix phosphoproteins for remineralization of artificial caries-like dentin. Dent Mater $2011 ; 27: 465-477$.
16. Li X, Munck J De, Landuyt K Van, Pedano M, Chen Z, Meerbeek B Van How effectively do hydraulic calcium-silicate cements re-mineralize demineralized dentin. Dent Mater 2017;33:434-445.

17. Aggarwal V, Singla $M$, Yadav $S$, Yadav $H$, Ragini. Marginal Adaptation Evaluation of Biodentine and MTA Plus in 'open Sandwich' Class II Restorations. J Esthet Restor Dent 2015;27:167-175.

18. Nakamura VC, Kataoka SHH, Gavini G, Ferrari PH, Cai S. FE-SEM evaluation of dental specimens prepared by different methods for in vitro contamination. Int J Dent 2012;2 Article ID 748471, 5 pages.

19. Jia $R, L u ~ Y$, Yang CW, Luo $X$, Han $Y$. Effect of generation 4.0 polyamidoamine dendrimer on the mineralization of demineralized dentinal tubules in vitro. Arch Oral Biol 2014;5910:1085-1093.

20. Tsortos A, Nancollas GH. The role of polycarboxylic acids in calcium phosphate mineralization. J Colloid Interface Sci 2002;250:159-167.

21. Malkondu Ö, M KKKE, M K. A review on Biodentine, a contemporary dentine replacement and repair material. BioMed Research International 2014 Article ID 160951, 10 pages.

22. Allen AJ, Thomas JJ, Jennings HM. Composition and density of nanoscale calcium-silicate-hydrate in cement. Nat Mater 2007;6:311316.

23. Camilleri J. Hydration characteristics of Biodentine and Theracal used as pulp capping materials. Dent Mater 2014;30:709-715.

24. Ozbay G, Kitiki B, Peker S, Kargul B. Apical sealing ability of a novel material : analysis by fluid filtration technique. Acta Stomatol Croat 2014:48:132-139.

25. Gandolfi MG, Taddei P, Siboni F, Modena E, Ciapetti G, Prati C. Development of the foremost light-curable calcium-silicate MTA cement as root-end in oral surgery. Chemical-physical properties, bioactivity and biological behavior. Dent Mater 2011;27:10-11.

26. Camilleri J, Laurent P, About I. Hydration of Biodentine, Theracal LC, and a prototype tricalcium silicate-based dentin replacement material after pulp capping in entire tooth cultures. J Endod 2014;40:18461854.

27. Dubey A. Review Article Calcium Hydroxide in Dentistry. 2016;5:3-7.

28. Ten Cate A. Hard tissue formation and destruction. Oral histology: development, structure and function. 5th ed., Mosby, St Louis, 1998;PP 69-77.

29. Birkedal-Hansen H. Oral histology: Cell structure and function. Am J Orthod Dentofac Orthop 1987;92:523-524.

30. Goldberg M, Takagi M. Dentine proteoglycans: composition, ultrastructure and functions. Histochem J 1993;25:781-806.

31. Kim YK, Mai S, Mazzoni A, Liu Y, Tezvergil-Mutluay A, Takahashi K, et al. Biomimetic remineralization as a progressive dehydration mechanism of collagen matrices - Implications in the aging of resin-dentin bonds. Acta Biomater. 2010;6:3729-3739.

32. Burwell AK, Thula-Mata T, Gower LB, Habeliz S, Kurylo M, Ho SP, et al. Functional remineralization of dentin lesions using polymer-induced liquid-precursor process. PLoS One 2012;7:7-8.

33. Liang $\mathrm{K}$, Xiao $\mathrm{S}, \mathrm{Wu} \mathrm{J}$, Li J, Weir MD, Cheng $\mathrm{L}$, et al. Long-term dentin remineralization by poly(amido amine) and rechargeable calcium phosphate nanocomposite after fluid challenges. Dent Mater 2018;34:607-618.

34. Ryou H, Niu LN, Dai L, Pucci CR, Arola DD, Pashley DH, et al. Effect of biomimetic remineralization on the dynamic nanomechanical properties of dentin hybrid layers. J Dent Res 2011;90:1122-1128.

Received July 30, 2019 Accepted November 20, 2019 